\title{
Establishment of Food Processing Methods for Larvae of Allomyrina dichotoma, Korean Horn Beetle
}

\author{
Mi Yeon Chung, Eun-Young Kwon, Jae-Sam Hwang, Tae-Won Goo and Eun-Young Yun*
}

Department of Agricultural Biology, National Academy of Agricultural Science, RDA, Suwon 441-100, Korea

Received January 15, 2013 /Revised March 22, 2013 /Accepted March 25, 2013

\begin{abstract}
With the objective of developing a functional food source, we established optimal processing conditions for the larvae of Allomyrina dichotoma, which have been used in traditional medicine to treat hepatic disorders in Korea. Without suitable processing, the larvae are difficult to consume as a food because of their disgusting taste and smell; moreover, in this form they might be a potential microbial hazard. In this study, we investigated the effect of feeding material, sterilization, and powdering after freeze-drying on the food quality of the larvae of $A$. dichotoma and on cytotoxicity against Raw 264.7 cells. Three to five days feeding with the sawdust from discarded oak-trees is sufficient for the breeding process. The sawdust was sterilized by vapor for five minutes. Sterilization of the larvae at a high temperature $\left(115^{\circ} \mathrm{C}\right.$ for $\left.5 \mathrm{~min}, 0.9 \mathrm{kgf} / \mathrm{cm}^{2}\right)$ is necessary to eliminate pathogenic bacteria and fungi. The results of the cytotoxicity assay showed no toxicity in the prepared extract from larvae of $A$. dichotoma. In addition, to prepare the larvae for human consumption, various feeds were used and the smell, color, and taste were evaluated. Our results suggested that larvae of $A$. dichotoma could be developed as food source when a suitable processing method is established.
\end{abstract}

Key words : Allomyrina dichotoma, food, cytotoxicity, preference survey

\section{서 론}

최근 곤충자원의 탐색, 보전을 통한 생물자원 확보경쟁이 날로 치열해지고 있는 가운데 이들의 가치평가 및 이용개발 연구가 매우 활발히 수행되고 있다. 이 가운데 전통적인 생약 으로 이용되어온 약용곤충의 예는 매우 다양하며, 효능 및 유 효성분 분석연구는 최근 들어 각광을 받고 있다. 그러나 국내 식품의약품안전청(Korea Food \& Drug Administration, $\mathrm{KFDA})$ 의 식품공전에 등록되어 식용으로 유통 및 판매가 가능 한 곤충은 누에(Bombyx mori larva, pupa)와 벼메뚜기(Oxya chinensis sinuosa) 외에는 전무한 실정 $[1,2,7,8,10,11]$ 이므로 곤충을 식품원료로 인정하기 위한 식약청의 허가가 시급한 실정이다. 이를 위해 이들 유용곤충의 약효 평가 및 안전성 평가가 필수적이다.

민간에서 오랫동안 한약제로 사용되고 있는 약용곤충 중 딱정벌레목에 속하는 장수풍뎅이과 장수풍뎅이 유충은 한약 제명으로 제조(蠐螬)라고 부르며 이는 예로부터 간에서 비롯 되는 간암, 간경화, 야뇨증, 간염, 유방암, 피로회복, 미용, 중

\footnotetext{
*Corresponding author

Tel : +82-31-290-8576, Fax : +82-31-290-8543

E-mail : yuney@korea.kr

This is an Open-Access article distributed under the terms of the Creative Commons Attribution Non-Commercial License (http://creativecommons.org/licenses/by-nc/3.0) which permits unrestricted non-commercial use, distribution, and reproduction in any medium, provided the original work is properly cited.
}

풍 등의 성인병 치료 및 예방에 탁월한 효능을 지닌다고 평가 되어있다[4]. 현재 장수풍뎅이에 대한 생육특성에 대한 연구 가 이루어져있으며[6], 또한 효능에 대한 연구로는 장수풍뎅 이 렉틴의 사이토카인 생성양상에 대한 연구와 간 손상 보호 효과에 대한 연구가 보고되었으며 $[3,5]$, 지표성분의 분리에 대한 연구가 보고되어 있다[9]. 그러나 장수풍뎅이 유충에 대 한 활발한 연구 및 민간에서의 식 - 약용으로의 이용 및 소비 가 증가되고 있지만 식품의약품안전청에서 식품으로 허가하 지 않고 있어 그에 대한 연구 및 이용이 제한적일 수 밖에 없다. 식품원료로서 이를 활용하기 위해서 식약청의 허가를 받을 수 있도록 2010년부터 식약청에서 시행하고 있는 '한시 적 인정제도'에 따라 '새로운 식품원료의 안전성 평가 가이드 라인'에 부합되는 새로운 식품원료의 안전성 등을 평가한 후 식약청에 한시적 인정을 받아야 식품으로 사용이 가능하다 [12]. 따라서 우선적으로 식품원료화를 위한 전처리 조건을 확립하여 안전성을 검증할 필요가 있다. 그러므로 본 연구에 서는 식 · 약용으로서 이용을 증대하기 위해 세균을 제거하고 장수풍뎅이 유충 특유의 이취제거 및 안전성 검증을 통한 전 처리 조건을 설정함으로써 식품원료로의 사용을 꾀하고 농가 소득을 증대할 수 있는 분말 제조의 최적조건을 확립하고자 하였다.

\section{재료 및 방법}

장수풍뎅이 유충 준비 및 미생물 검사 장수풍뎅이는 국내산 가나안 농원(경상남도 거제)에서 참 
나무 버섯폐목 톱밥으로 키운 종령인 3령 유충을 분양 받아 이용하였다.

장수풍뎅이 현탁액을 식 · 약용 소재로 사용하기 위해서는 세균 및 곰팡이와 같은 미생물이 없어야 하므로 바람직한 조 건을 확립하기 위해, 멸균시간 및 온도를 조절하여 사료 및 유충분말의 최적조건을 조사하였다.

장수풍뎅이 유충의 먹이로 사용되는 참나무 버섯폐목 톱밥 은 $5,10,20,30$ 분 동안 수증기로 멸균하였고, 장수풍뎅이 유충 은 $115^{\circ} \mathrm{C}, 0.9 \mathrm{kgf} / \mathrm{cm}^{2}$ 와 $121^{\circ} \mathrm{C}, 1.3 \mathrm{kgf} / \mathrm{cm}^{2}$ 으로 각 5 분, 10 분 동안 고온고압 멸균하였으며, 이들 각 조건의 분말을 제조 후 증류수로 $10^{-3}$ 농도로 희석하고 이를 고체 $\mathrm{LB}$ 배지에 도말평판 법으로 접종하여 24 시간 동안 $37^{\circ} \mathrm{C}$ 에 배양 후 세균군집 (colony) 생성여부를 확인하였다.

\section{장수풍뎅이 분말 및 현탁액 제조}

장수풍뎅이 3령 유충을 고온 멸균한 참나무 버섯폐목(참나 무톱밥; 가나안 농원, 경남 거제)으로 3일 동안 사육한 후 액체 질소를 부어 급속 동결하여 $-70^{\circ} \mathrm{C}$ 의 초저온 냉동고( $\mathrm{NIHON}$ freezer, Tokyo, Japan)에 24시간 동안 동결시켰다. 그리고 11 $5^{\circ} \mathrm{C}, 5$ 분간 멸균한 후 동결 건조기(Eyela, Tokyo, Japan)를 이 용하여 수분을 제거하였다. 수분을 제거한 장수풍뎅이를 분쇄 기(다기능분쇄기, KSP-35, Korea)로 분쇄하여 분말을 제조하 였다. 분말 현탁액 제조를 위해 분말을 $70 \%$ 에탄올에 용해시 킨 후 초음파 파쇄기(Sonics Vibra cell sonicator, LabaX, Messachusetts, USA)로 230jule, 10초간 세포막 파쇄 후 4500 $\mathrm{rpm}$ 에서 20분 동안 원심분리 하여 상층액 회수 후 $0.25 \mu \mathrm{m}$ syringe filter로 여과 하고 건조시켜 시료로 사용하였다.

\section{대식세포 생존율 시험}

장수풍뎅이 유충 분말의 대식세포인 Raw 264.7 세포에 대 한 독성 여부를 측정하기 위해 고온 멸균한 참나무 톱밥으로 사육한 장수풍뎅이 유충을 1 일 절식 후 배변 유도 하였다. 배 변을 유도한 장수풍뎅이 유충은 멸균한 그룹과 멸균을 하지 않고 분말을 낸 두 그룹으로 나누어서 $70 \%$ 에탄올에 용해시킨 후 초음파에 의해 물질추출 후 이를 농도 별 $(10,100,500$ 및 $1,000 \mu \mathrm{g} / \mathrm{ml}$ )로 RAW 264.7 세포에 처리하여 세포 생존율을 측정하였다. 생쥐의 대식세포주인 Raw 264.7 세포는 penicillin-streptomycin $100 \mathrm{unit} / \mathrm{ml}$ 과 10\% fetal bovine serum
(FBS, Gibco, Grand Island, USA)이 함유된 Dublecco's Modified Eagle Medium (DMEM, Gibco, Grand Island, USA) 배지를 사용하여 $37^{\circ} \mathrm{C}, 5 \% \mathrm{CO}_{2}$ incubator (Dosol, Korea)에서 배양하였으며, 2 일 간격으로 계대 배양을 실시하였다. 세포 생존율 측정을 위해 Raw 264.7 세포를 $1 \times 10^{6} \mathrm{cells} / \mathrm{ml}$ 농도로 96 well plate에 분주하고 장수풍뎅이 분말 추출물을 농도 별 처리 후 $37^{\circ} \mathrm{C}, 5 \% \mathrm{CO}_{2}$ incubator에서 24시간 배양하였다. CellTiter $96 \circledast \mathrm{AQueous}$ non-radioactive cell proliferation assay (MTS, Promega, Hollywood, USA)를 $20 \mu \mathrm{l} /$ well로 첨가 한 후, $37^{\circ} \mathrm{C}, 5 \% \mathrm{CO}_{2}$ incubator에서 4 시간 반응시켜 microplate reader (Beckman, USA)를 이용하여 $450 \mathrm{~nm}$ 에서 흡광도 를 측정하여 세포 생존율을 측정하였다.

\section{장수풍뎅이 유충의 이취 제거를 위한 관능평가}

다양한 조건에 의한 장수풍뎅이 유충 동결건조 분말제조 후 사람의 후각과 시각을 이용한 관능평가를 실시하여 특유의 이취 감소조건을 조사하였다. 이취감소 및 소화 촉진에 효과 적이며 경제적이라 사료되는 5 가지 채소 및 곡물(무, 양파, 양 배추, 쌀겨 발효품, 밀가루)을 5 일간 먹인 유충으로부터, 제조 된 장수풍뎅이 유충 분말을 건강한 성인 남녀 20명을 무작위 로 선발해 관능평가를 실시하였다. 유충이 지니고 있는 특유 의 이취는 주로 먹이와 장내에 존재하는 물질에서 야기되는 것이므로 사료 섭취 후 $1 \sim 5$ 일 동안 굶기면서 배변 활동을 유도 한 후 이취여부를 평가하였다. 1 차 관능평가에서는 각 군마다 악취가 나지 않는 일수를 정하였고, 2 차 관능평가에서는 1 차 로 선별된 샘플 중에서 냄새와 색을 평가하였다.

\section{결과 및 고찰}

\section{장수풍뎅이 유충 및 사료 살균조건 설정}

식품원료화를 위한 장수풍뎅이 유충의 분말 제조를 위해 장수풍뎅이 유충은 절식 전 살균한 참나무 버섯폐목 톱밥을 3 일 이상 먹여서 사육하는 것이 장수풍뎅이 유충 체내 미생물 수를 감소시킬 뿐만 아니라 유충의 분말 이취를 감소시킴을 확인하였다. 또한 장수풍뎅이 유충의 먹이로 사용되는 참나무 버섯폐목은 고온의 증기 $\left(70^{\circ} \mathrm{C}\right.$ 이상 $)$ 로 살균하여 세균 및 진균 유무를 확인한 결과 스팀으로 5 분간 쪄도 미생물이 검출되지 않았으며(Table 1) 장수풍뎅이 유충 배변 유도 후 고압멸균기

Table 1. Microbial risk assessment of the sawdust after sterilization

\begin{tabular}{ccccc}
\hline No. & Steam time $(\mathrm{min})$ & Dilution factor & Fungi $\left(\times 10^{5} \mathrm{cfu} / \mathrm{g}\right)$ & Bacteria $\left(\times 10^{5} \mathrm{cfu} / \mathrm{g}\right)$ \\
\hline 1 & - & $10^{-3}$ & $15.9 \times 10^{4}$ & $4.7 \times 10^{4}$ \\
2 & 5 & $10^{-3}$ & $\mathrm{ND}^{1)}$ & $\mathrm{ND}^{1)}$ \\
3 & 10 & $10^{-3}$ & $\mathrm{ND}^{1)}$ & $\mathrm{ND}^{1)}$ \\
4 & 15 & $10^{-3}$ & $\mathrm{ND}^{1)}$ & $\mathrm{ND}^{1)}$ \\
5 & 20 & $10^{-3}$ & $\mathrm{ND}^{1)}$ & $\mathrm{ND}^{1)}$ \\
\hline
\end{tabular}

\footnotetext{
${ }^{1)}$ ND: Not Detected.
} 
Table 2. Microbial risk assessment of the powder of Allomyrina dichotoma larvae after sterilization

\begin{tabular}{ccccc}
\hline No. & Sterilization condition & Dilution factor & Fungi $\left(\times 10^{5} \mathrm{cfu} / \mathrm{g}\right)$ & Bacteria $\left(\times 10^{5} \mathrm{cfu} / \mathrm{g}\right)$ \\
\hline 1 & - & $10^{-3}$ & $15.9 \times 10^{4}$ & $4.7 \times 10^{4}$ \\
2 & $115^{\circ} \mathrm{C}, 0.9 \mathrm{kgf} / \mathrm{cm}^{2}, 5 \mathrm{~min}$ & $10^{-3}$ & $\mathrm{ND}^{1)}$ & $\mathrm{ND}^{1)}$ \\
3 & $115^{\circ} \mathrm{C}, 0.9 \mathrm{kgf} / \mathrm{cm}^{2}, 10 \mathrm{~min}$ & $10^{-3}$ & $\mathrm{ND}^{1)}$ & $\mathrm{ND}^{1)}$ \\
4 & $121^{\circ} \mathrm{C}, 1.3 \mathrm{kgf} / \mathrm{cm}^{2}, 5 \mathrm{~min}$ & $10^{-3}$ & $\mathrm{ND}^{1)}$ & $\mathrm{ND}^{1)}$ \\
\hline
\end{tabular}

${ }^{1)} \mathrm{ND}$ : Not Detected.

를 이용하여 유충 자체를 멸균한 결과 $115^{\circ} \mathrm{C}, 0.9 \mathrm{kgf} / \mathrm{cm}^{2}$ 압력 에서 5 분간 멸균 처리시 세균 및 진균이 사멸됨을 확인 할 수 있었다(Table 2).

장수풍뎅이 유충의 배변 유도 후 멸균 유무에 따른 대식세 포 생존율

장수풍뎅이 종령 유충의 식품원료화를 위해 이취감소를 위 한 방법으로 장수풍뎅이 유충의 절식을 통한 배변유도를 실시 하였으며 이들 유충에 대한 멸균 및 비멸균 상태에서의 세포 독성 여부를 확인한 결과 절식을 통한 배변유도 후 멸균하여 제조한 분말과 멸균과정 없이 제조한 분말 시료 모두 대조군 에 비해 $1,000 \mu \mathrm{g} / \mathrm{ml}$ 의 고농도의 조건에서도 세포생장률이 저해되지 않아 뚜렷한 독성이 측정되지 않음을 확인 할 수 있었다(Fig. 1).

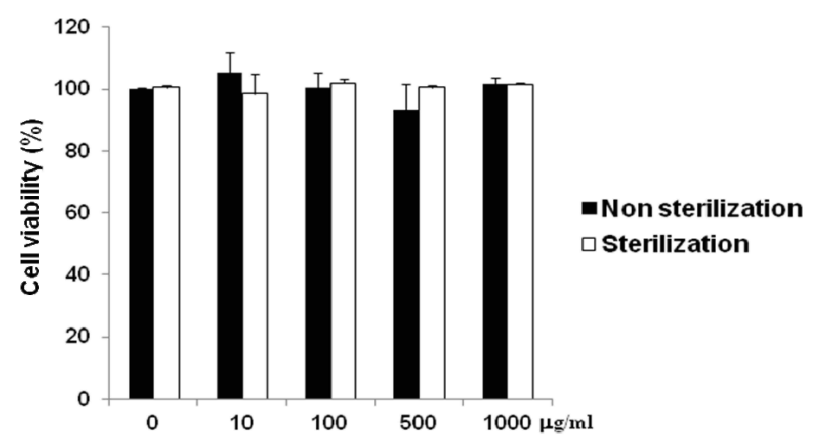

Fig. 1. Cytotoxicity of sterilized and non-sterilized extract of Allomyrina dichotoma larva against Raw 264.7 cell. Values are mean \pm S.D.
장수풍뎅이 유충의 이취감소를 위한 관능평가

식품원료로 사용시 식품으로부터의 고유의 이취는 소비자 의 기호도를 감소시킬 수 있는 중요 원인이 될 수 있다. 이로 인해 동결 건조된 장수풍뎅이 유충분말에서의 이취는 소비자 의 기호에 이롭지 않은 영향을 끼칠 수 있을 것이라 판단되어 우선적으로 장내 이물질에서 발생하는 이취 제거를 위해 먹이 공급중단을 통한 장 내 이물질 제거를 유도하였다. 이 때 살균 처리된 참나무 버섯폐목 톱밥을 3 일간 공급 한 후 10 일간 절식 하였으며 이 과정을 통해 장 내 배변을 유도 하였다. 그러나 Fig. 2 에서 보는 바와 같이 10 일간의 절식 상태에서도 장내 배설물의 정도가 눈에 띠게 감소하지 않았으며 오히려 5일 이상의 절식에서는 장수풍뎅이 유충의 생존율이 감소함을 관 찰 할 수 있었다(data not shown). 이러한 결과를 통해 장수풍 뎅이의 경우 절식을 통한 장내 배변 촉진은 효과적이지 않음 을 확인할 수 있었다. 따라서 보다 효율적인 배변촉진을 위해 소화촉진 및 이취제거에 효과적이라 사료되는 식품들(무, 양 파, 양배추, 쌀겨 발효품, 밀가루)을 공급함으로써 5 일간 배변 활동을 유도하여 장내 이물질 제거 정도를 확인하였고 이들 각각의 실험 군을 동결 건조시켜 유충 분말의 색의 밝기 및 냄새에 대한 관능평가를 실시하였다. 이 때 유충 무게 변화가 크지 않았던 1 5일간 대체먹이 없이 절식유도 그룹 또한 비교 관찰 하였다. 이들 먹이그룹의 차에 따른 유충 장 해부를 통한 장내 정체물의 여부를 확인해본 결과 먹이의 차이는 배변 유 도에 영향을 미치지 않음을 확인할 수 있었다(Fig. 3A). 또한 5 일간 배변유도 기간 중 날짜 별로 체중의 변화를 확인한 결과 양파와 밀가루 섭취그룹에서 체중감소가 눈에 띄었고, 특히

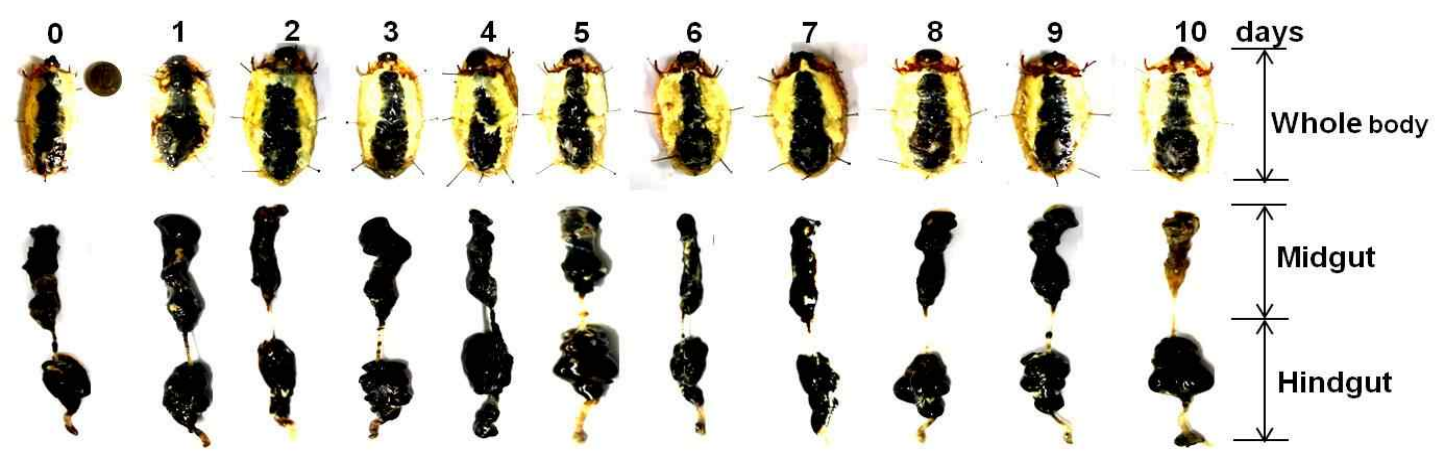

Fig. 2. The dissected photograph of Allomyrina dichotoma larva after fasting for 10 days. 
밀가루 섭취 그룹의 경우 3 일째부터 장내 물질이 대체먹이로 변하는 듯 했으나 4일째 모두 치사하여(Fig. 3B) 대체먹이로 효율적이지 않음을 알 수 있었다. 먹이그룹 차에 따른 경우의 수가 많음에 따라 정확한 판단을 위해 관능평가는 1 차와 2 차 로 나누어 실시하였다. 우선 1 차 관능평가는 냄새를 기준으로 조사하였으며 먹이 별로 최고의 선호도를 나타내는 조건을 하나씩 선택한 결과 무 5일간 섭취 그룹( $38 \%)$, 양파 2일간 섭 취 그륩 $(59 \%)$, 양배추 3 일 섭취 그룹( $47 \%)$, 발효 쌀겨 섭취 그룹(59\%), 밀가루 1 일 섭취그룹(72\%) 그리고 1 일 절식 그룹
(66\%)로 평가되었다(Fig. 3C). 1차 관능평가를 기준으로 선별 된 시료에 대해 2 차 색과 풍미에 대한 관능평가를 실시한 후 최종적인 선호도를 조사한 결과 1 일간 절식 유충 건조물 $(38 \%)$, 무 5일 섭취그룹(22\%) 그리고 밀가루 1일 섭취그룹 $(18 \%)$ 순으로 높게 평가되었다(Fig. 4). 이러한 결과를 토대로 경제성과 편리성을 고려하였을 때 1 일 절식 후 배변 유도한 유충 건조물이 식품을 위한 전처리 조건에 가장 적합할 것이 라고 판단되었다.

본 연구 결과는 장수풍뎅이 종령 유충을 식품원료로 사용하

A
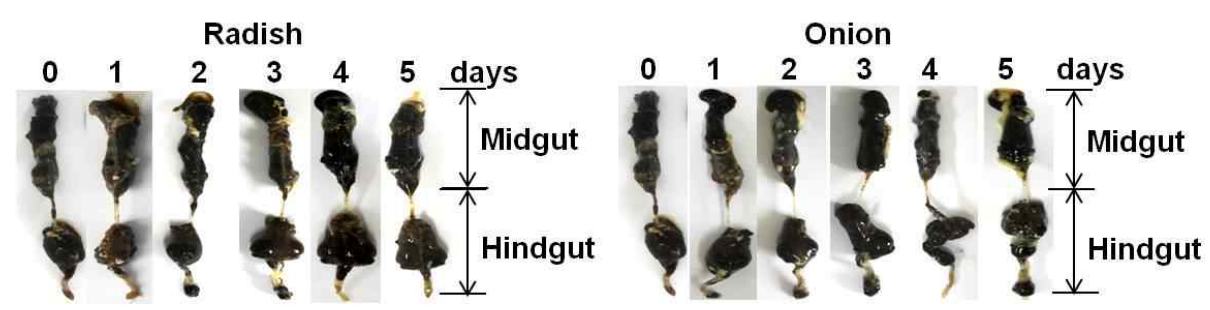

Chinese cabbage

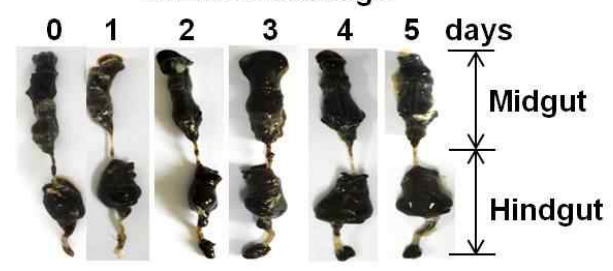

Fermented rice bran

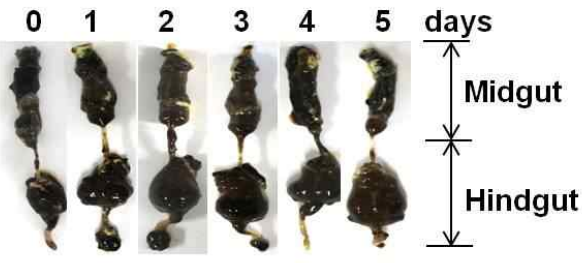

Wheat flour
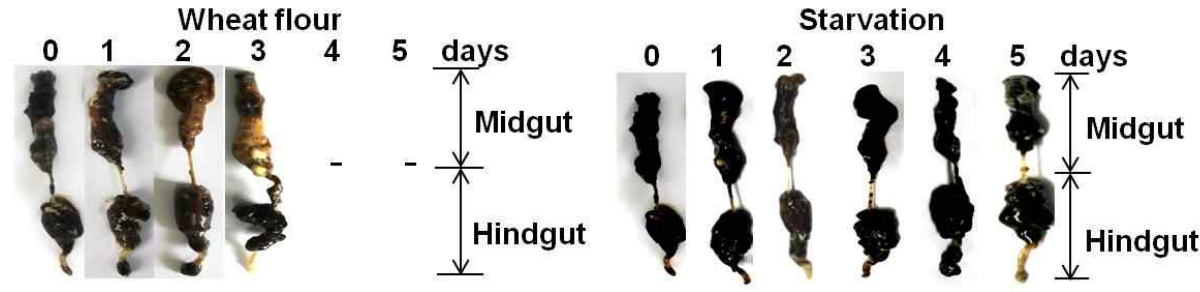

B

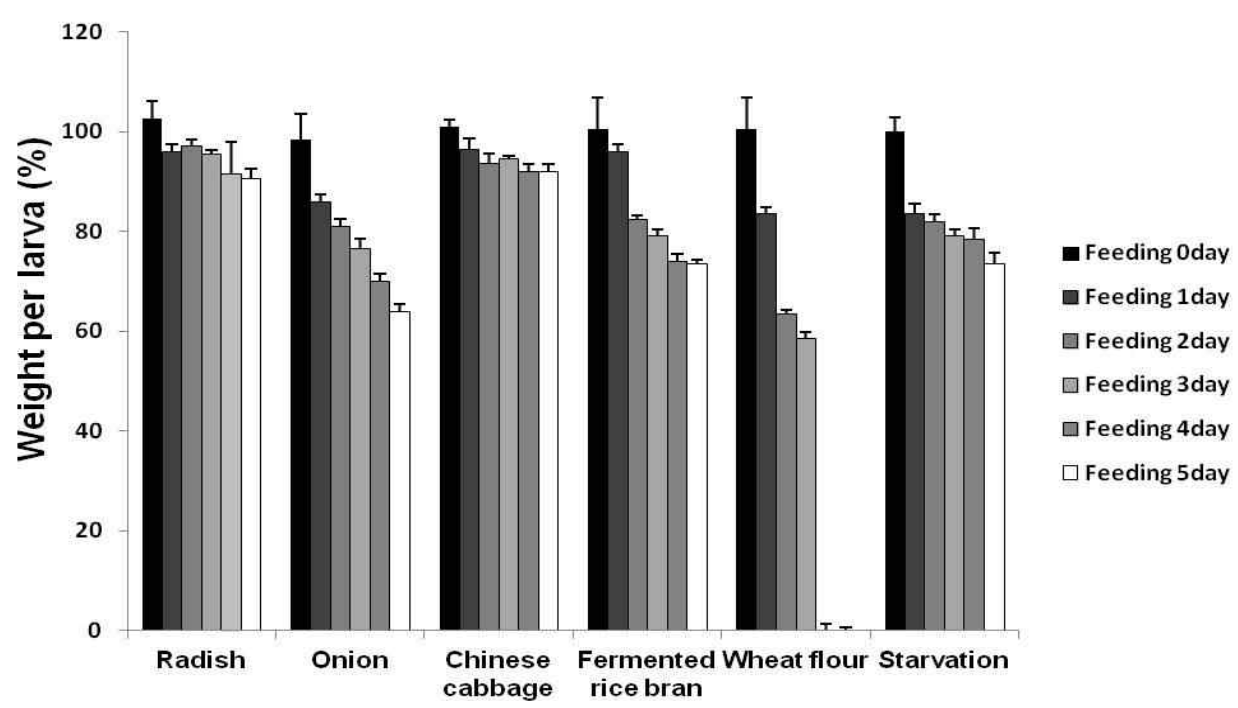

Fig. 3. The image of gastro-intestinal track (a), weight of Allomyrina dichotoma larva (b), and sensory evaluation ( $\mathrm{n}=20)$ of $A$. dichotoma larvae after feeding of various food materials (c). Values are mean \pm S.D. 


\section{C}

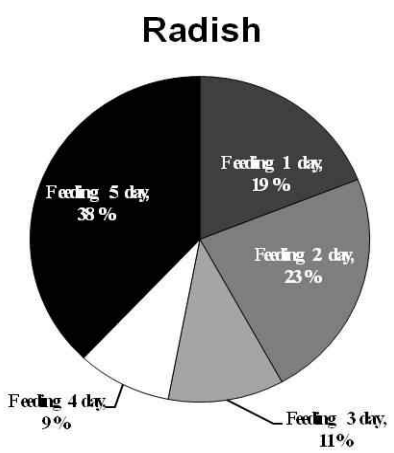

Chinese cabbage

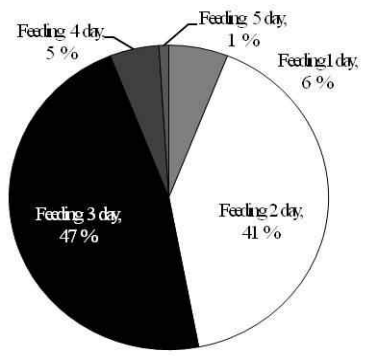

Wheat flour

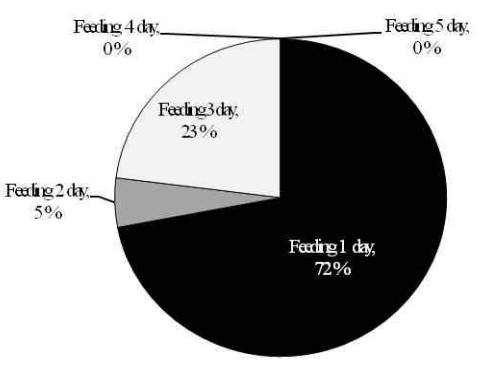

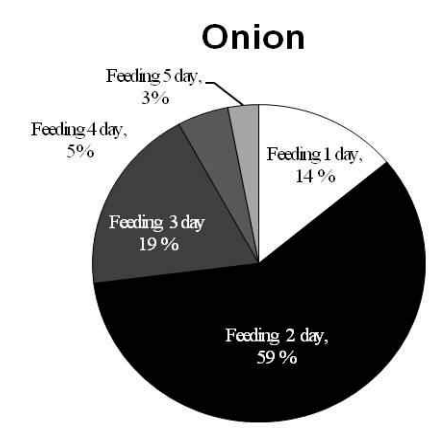

Fermented rice bran

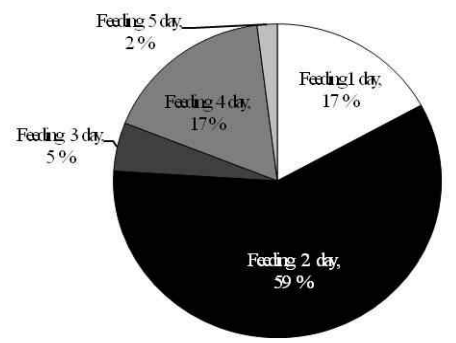

Starvation

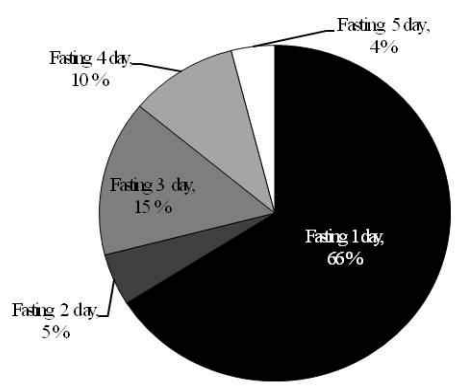

Fig. 3. Continued

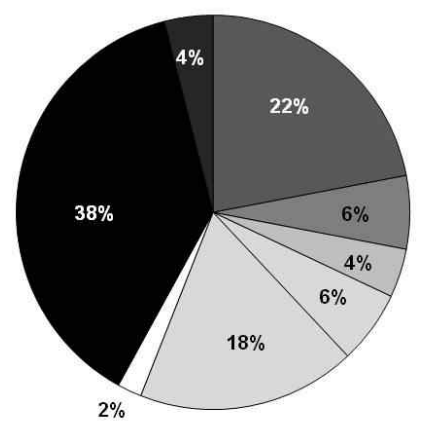

口adish, 5day $\square$ Chinese cabbage, 3day $\square$ Wheat flour, 1 day -Starvation, 1 day $\square$ Fermented rice bran, 2 day $\square$ Onion, 2day

$\square$ Starvation, Oday

- Starvation, 2day

Fig. 4. Preferences of the Allomyrina dichotoma larva powder, which is prepared from larva feeding of various food materials.

기 위한 세포 독성 측정 및 특유의 이취 감소 및 살균조건의 표준화를 확립함으로써 식품원료화를 위한 전처리 조건을 설 정하는데 기여하였으며 이를 통해 장수풍뎅이 유충을 식품원 료로서 생산하기 위한 조건을 설정하는데 필요한 유익한 정보 를 얻었다고 생각된다.

$$
\text { 감사의 글 }
$$

본 연구는 농촌진흥청에서 지원하는 어젠다 프로그램 (\#PJ008969)의 연구수행으로 인한 결과물임을 밝힙니다.

\section{References}

1. Cha, C. H., Kim, Y. S., Ahn, H. Y., Eom, K. E., Park, B. K., Jun, B. S. and Cho, Y. S. 2009. Biological activity of fermented silkworm powder. J Life Sci 19, 1468-1477. 
2. Cho, C. H., Cha, W. S. and Kim, J. S. 1989. Effect of temperature, time and $\mathrm{pH}$ on the extraction of protein in a chrysalis of silkworm. Korean J Biotechnol Bioeng 4, 65-488.

3. Choi, Y. H., Lee, K., Yang, K. M., Jeong, Y. M. and Seo, J. S. 2006. Effect of larva extract of Allomyrina dichotoma on carbon tetrachloride-induced hepatotoxicity in mice. $J$ Korean Soc Food Nutr 35, 1349-1355.

4. Heo, J. 2009. In Dongeui Bogam, 3rd ed., NansanDang Press, Seoul, 576 .

5. Jeune, K. H., Kim, S. J. and Chung, S. R. 2005. Cytokine expression with lectins from Allomyrina dichotoma and Bombyx mori. Korean J Pharmacogn 36, 129-135.

6. Kim, H. G. and Kang, K. H. 2005. Bionomical characteristic of Allomyrina dichotoma. Korean J Appl Entomol 44, 207-212.

7. Kim, T. S., Lee, J. H., Choi, B. D. and Byu, H. S. 1987. Nutritional value of dried paddy grasshopper, Oxya chinensis formosana. J Korean Soc Food Nutr 16, 98-104.

8. Lee, J. H., Kim, T. S., Choi, B. D., Kim, G. E. and Lee, K.
H. 1987. Effects of containing pigments of dried grasshopper on the lipid deterioration. J Korean Soc Food Nutr 16, 300-305.

9. Lee, J. H., Song, M. C., Yang, H. J., Bang, M. H., Chung, D. J., Kim, Y. C., Kim, S. Y., Rho, Y. D., Chung, S. H. and Baek, N. I. 2006. Isolation and quantitative analysis of inosine as an index component from larva of Allomyrina dichotoma. J Korean Soc Appl Biol Chem 49, 334-338.

10. Lee, S. K. 1978. Studies on the development of cocoon pupas for food materials. Korean J Nutr 11, 39-43.

11. Park, J. H., Kim, S. Y., Kang, M., Yoon, M., Lee, Y. I. and Park, E. 2012. Antioxidant activity and safety evaluation of juice contaning Protaetia brecitarsis. J Korean Soc Food Sci Nutr 41, 41-48

12. Shon, M. G., Kim, M. C., Goo, W. E., Shin, H. S., Kim, H. K., Kim, J. M., Oh, J. M., Lee, S. Y., Ha, J. U., Park, N. K., Lee, J. K., Choi, K. H. and Ahn, J. H. 2010. Safety assessment guideline of new food base material. KFDA.

\section{초록 : 식약용으로의 장수풍뎅이 유충 전처리 방법에 대한 연구}

정미연 · 권은영 · 황재삼 · 구태원 · 윤은영*

(농촌진흥청 국립농업과학원 농업생물부)

본 연구에서는 장수풍뎅이 유충의 식품원료화를 위한 전처리 조건을 설정하기 위해 세포독성을 평가하고 특유 의 이취감소 및 살균조건을 확립하였다. 분말 전처리 조건으로 수증기로 5 분, 10 분, 20 분, 30 분 동안 수증기로 멸균한 버섯폐목에 대한 미생물 검사 결과, 5 분 이상 수증기로 멸균한 버섯폐목사료에 대해 미생물이 전혀 검출 되지 않았다. 또한 수증기로 5 분간 멸균한 사료로 사육한 장수풍뎅이 유충을 $115^{\circ} \mathrm{C}, 0.9 \mathrm{kgf} / \mathrm{cm}^{2}, 121^{\circ} \mathrm{C}, 1.3$ $\mathrm{kgf} / \mathrm{cm}^{2}$ 의 고온고압 멸균기 멸균하여 동결건조한 분말을 분쇄기로 분쇄하여 분말을 제조하였으며 이에 대한 미 생물 검사를 실시한 결과, 모든 그룹에서 미생물이 전혀 검출되지 않았다. 이로써 5 분간 살균한 사료로 사육한 장수풍뎅이 유충을 $115^{\circ} \mathrm{C}, 0.9 \mathrm{kgf} / \mathrm{cm}^{2}$ 으로 멸균하여 식품화 원료로 사용하기에 적합하다고 판단하였다. 그러나 이들 분말시료에서 나는 고유의 이취는 소비자의 기호도를 감소시킬 수 있는 중요한 원인이 될 수 있다고 판단되 어 먹이공급중단을 통한 장내 이물질 제거를 유도하였으나 1 일 10 일까지의 먹이공급중단에 따른 장내 배설물의 정도가 눈에 띠게 감소하지 않고 5 일 이상의 먹이공급중단에 따른 생존율이 감소함이 관찰되었다. 따라서 절식을 통한 장내 배변촉진이 효과적이지 않음을 확인하였으며 이에 소화촉진 및 이취제거에 효과적이라 사료되는 식품 들(무, 양파, 양배추, 발효쌀겨, 밀가루)을 공급하여 5 일간 배변 활동을 유도한 결과 먹이의 차이는 배변유도에 영향을 미치지 않음을 확인 할 수 있었다. 이에 배변유도에 따른 이취감소가 아닌 대체 먹이 사육 및 절식에 따른 후각 및 시각에 대한 관능평가를 실시한 결과 경제성과 편리성을 고려하였을 때 1 일 절식 후 배변 유도한 유충 건조물이 식품을 위한 전처리 조건에 가장 적합할 것이라고 판단되었다. 또한 멸균한 사료로 사육한 장수풍뎅이 유충의 세포독성을 평가한 결과 $1,000 \mu \mathrm{g} / \mathrm{ml}$ 의 고농도에서 세포독성이 없음을 확인하였다. 이로써 본 연구에서 1 일간 절식 후 배변 유도한 유충 건조물이 식품을 위한 전처리 조건에 가장 적합할 것이라고 판단되며 장수풍뎅 이 유충의 전처리 조건설정을 통한 식품원료로서의 안전성을 확보하고 경제적 산업적 측면에서의 활용이 가능할 것이라고 사료된다. 